\title{
SERUM INHIBITION OF STREPTOCOCCAL DIPHOSPHOPYRIDINE NUCLEOTIDASE IN UNCOMPLICATED STREPTOCOCCAL PHARYNGITIS AND IN RHEUMATIC FEVER *
}

\author{
By GERSON C. BERNHARD † AND GENE H. STOLLERMAN \\ (From the Department of Medicine, Northwestern University Medical School, Chicago, Ill.)
}

(Submitted for publication June 8, 1959; accepted July 23, 1959)

One of the recently described extracellular products of Group A streptococci is diphosphopyridine nucleotidase (DPNase) (1). This enzyme has received attention as a substance of possible importance in the etiology of either rheumatic fever or glomerulonephritis because $a$ ) it was isolated from cardiotoxic fractions of supernates of broth cultures of Group A streptococci $(2,3)$ and $b$ ) almost all nephritogenic strains of Group A streptococci studied produced it in vitro (4).

Kellner, Freeman and Carlson (5) showed that the inhibition of DPNase by human sera of different age groups follows the pattern of other streptococcal antibodies and that DPNase neutralizing titers increase in response to streptococcal infection. -

Studies in progress in this laboratory on rheumatic fever and the human immune response to streptococcal infection afforded the opportunity to compare the behavior of the antibody response to DPNase with antibody responses to some other known antigenic extracellular enzymes of the streptococcus. This report presents further evidence that antistreptococcal DPNase activity (ASDA) of human sera behaves as a specific antibody and that it reflects streptococcal disease in rheumatic and nonrheumatic individuals in a manner very similar to antistreptolysin $\mathrm{O}$, antihyaluronidase and antistreptokinase titers.

\section{MATERIALS AND METHODS}

The method employed for the assay of DPNase and antiDPNase was based upon that described by Carlson,

* These studies were conducted in the Samuel J. Sackett Research Laboratories and supported in part by Research Grant H-2623 from the National Heart Institute, Public Health Service, Bethesda, Md.

$\dagger$ Fellow in Medicine, Northwestern University Medical School. Supported by Graduate Training Grant NIH 2A-5069 from the National Institute of Arthritis and Metabolic Diseases, Public Health Service, Bethesda, Md.
Kellner, Bernheimer and Freeman (1), with some modifications. Streptococcal DPNase activity was measured by determining the enzymatic degradation of a standard amount of DPN. ASDA was determined by measuring the inhibition of DPNase activity by serial dilutions of human serum.

Preparation of streptococcal DPNase. Partially purified streptococcal DPNase was prepared in the following manner. The C203S strain of Group A streptococci was grown in Todd-Hewitt broth for 18 hours, penicillin added (approximately 100 units per. $\mathrm{ml}$.), and the supernate separated from the streptococcal cells in a Sharples centrifuge at $4^{\circ} \mathrm{C}$. The enzyme in the supernate was precipitated with half saturated ammonium sulfate and dialyzed in cellophane bags against running tap water for 20 hours. The solution was concentrated by evaporation in cellophane bags to one-tenth of its original volume and centrifuged to remove precipitate. Aliquots of the supernate were frozen at $-70^{\circ} \mathrm{C}$. in a dry ice-alcohol bath and stored at $-65^{\circ} \mathrm{C}$. Prior to use in the assay of ASDA, aliquots of enzyme were thawed and diluted in a $0.1 \mathrm{M}$ phosphate buffer, $\mathrm{pH} 7.4$, containing 0.1 per cent bovine serum. Enzyme activity did not diminish significantly when the buffered solution was kept at $4^{\circ} \mathrm{C}$. for several days.

Assay of DPNase activity. DPNase activity was measured as follows. To each of four tubes ${ }^{1}$ was added $0.2 \mathrm{ml}$. of twofold serial dilutions (1:4 to $1: 32$ ) of crude enzyme and $0.8 \mathrm{ml}$. of a $1 \mathrm{mg}$. per $\mathrm{ml}$. solution of DPN.2 The mixture was incubated in a water bath of $37^{\circ}$ C. for 7.5 minutes. The reaction was stopped by plunging the tubes into an ice bath and promptly adding $6.0 \mathrm{ml}$. of $1 \mathrm{M}$ sodium cyanide solution freshly prepared. Control tubes in which buffer was substituted for enzyme and for substrate, respectively, were included with each assay. The optical density of the DPN-cyanide complex was read at $340 \mathrm{~m} \mu$ against a cyanide blank in a photocolorimeter. Originally the Beckman DU spectrophotometer was used. However, the Bausch and Lomb "Spectronic 20" colorimeter was found capable of measuring optical density at $340 \mathrm{~m} \mu$ with sufficient accuracy for the purposes of this assay and was also employed in this study. One unit of DPNase activity is defined as the amount necessary to destroy $0.01 \mu$ Mole of DPN at

\footnotetext{
${ }^{1}$ Kimball screw cap culture tubes $13 \times 75 \mathrm{~mm}$. were found convenient.

2 Nutritional Chemical Company supplied DPN powder of 95 per cent purity.
} 
$37^{\circ} \mathrm{C}$. in 7.5 minutes (6). A $1: 16$ dilution of the crude streptococcal enzyme employed destroyed approximately $0.5 \mu$ Mole of DPN under these conditions.

Titration of antistreptococcal DPNase $(A S D A)$ in serum. Serum to be tested for ASDA content was diluted serially twofold in phosphate buffer. Dilutions of $1: 4$ to $1: 256$ were sufficient to measure the range of antibody titers usually encountered in patients with streptococcal disease. To each tube was added $0.2 \mathrm{ml}$. of serum dilution and $0.2 \mathrm{ml}$. of DPNase solution (approximately 250 units). Control tubes containing enzyme without serum antibody, and substrate without enzyme, respectively, were included. All tubes were incubated at $37^{\circ} \mathrm{C}$. for 30 minutes to allow for combination of antigen and serum antibody and then were placed in an ice bath. To test residual DPNase activity, $0.6 \mathrm{ml}$. of DPN solution (1.33 $\mathrm{mg}$. per $\mathrm{ml}$.) was added to each tube and the same procedure followed as described above for the assay of DPNase.

The curve representing decrease in optical density due to enzymatic destruction of DPN is linear only to 60 per cent destruction. Therefore, inhibition of the decrease in optical density along the linear portion of the curve was the range used in the calculation of the ASDA titer. By arbitrary definition, one unit of antibody inhibits 100 units of DPNase (5). The ASDA titer was calculated from the serum dilution resulting most nearly in a 50 per cent inhibition of DPNase as follows: units of DPNase inhibited $\times$ reciprocal of serum dilution $X$ $10^{-2}$ units of antibody are expressed as the reciprocal of the serum dilution titer in the assay of most streptococcal antibodies. The same convention has been observed for expressing units of ASDA.

Other methods employed. Antistreptolysin O (ASO) determinations were made by the method of Rantz and Randall (7) ; antistreptokinase (ASK) by the method of Christensen (8) and antihyaluronidase ( $\mathrm{AH})$, by the method of Harris and Harris (9). Throat cultures were made by inoculating throat swabs directly on 5 per cent sheep blood agar plates. Beta hemolytic streptococcal colonies isolated were grouped and typed by conventional serological methods (10). All sera were frozen and stored at $-20^{\circ} \mathrm{C}$. or were placed in tightly capped vials and stored at $4^{\circ} \mathrm{C}$. Serum was clarified by centrifugation before determination of the ASDA titer.

\section{RESULTS}

\section{Specific antibody properties of $A S D A$}

In the preliminary stages of this study and before additional data of others were available, it was considered of importance to determine whether or not the streptococcal DPNase inhibitor in human serum had the properties of a specific antibody. In distinction to most nonspecific serum inhibitors, antibodies that neutralize streptococcal enzymes are relatively thermostabile $\gamma$-globulins
TABLE I

Replicate determinations of streptococcal antibodies in a pool of human serum

\begin{tabular}{lccc}
\hline \hline $\begin{array}{c}\text { Streptococcal } \\
\text { antibody* }\end{array}$ & $\begin{array}{c}\text { No. of } \\
\text { determinations }\end{array}$ & $\begin{array}{c}\text { Mean } \\
\text { titer }\end{array}$ & $\begin{array}{c}\text { Standard } \\
\text { deviation }\end{array}$ \\
\hline & & units $/ \mathrm{ml}$. & units $/ \mathrm{ml}$. \\
ASDA & 98 & 64 & 4.7 \\
ASO & 58 & 127 & 6.4 \\
AH & 33 & 136 & 19.3 \\
ASK & 27 & 80 & 4.0 \\
\hline
\end{tabular}

* ASDA = antistreptococcal diphosphopyridine nucleotidase $; \mathrm{ASO}=$ antistreptolysin $\mathrm{O} ; \mathrm{AH}=$ antihyaluronidase; ASK = antistreptokinase.

and are usually specific for the species from which the enzyme is derived.

Accordingly, some pools of human sera were studied for these properties. ASDA was unaffected by heating serum at $56^{\circ} \mathrm{C}$. for one hour. More than 95 per cent of ASDA activity recovered was localized in the fraction of serum precipitated by 0.33 ammonium sulfate saturation. Euglobulin fractions prepared in our laboratory from pools of human sera, and several commercial lots ${ }^{3}$ of human $\gamma$-globulin that were known to be high in ASO, ASK and AH activity, were also found to be relatively high in ASDA.

The species specificity of human serum inhibition of streptococcal DPNase was also confirmed. DPNase was prepared from beef spleen and was tested in parallel determinations with streptococcal DPNase against sera of known high ASDA titer. Beef spleen DPNase was not inhibited at all by sera that strongly inhibited streptococcal DPNase.

\section{The reproducibility of the $A S D A$ test}

The ASDA titration was compared with three other well known streptococcal antibody determinations (Table I). Replicate determinations were made on the same pool of human serum : 98 times for ASDA; 58 times for ASO; 33 times for $\mathrm{AH}$; and 27 times for ASK. The geometric mean titers and standard deviations were as follows: ASDA, 64 units per ml., \pm 4.7 ; ASO, 127 units per ml., \pm 6.4 ; ASK, 80 units per $\mathrm{ml} ., \pm 4.0$; and AH, 136 units per ml., \pm 19.3 .

The ASDA titers were calculated as actual units of enzyme inhibited per milliliter of serum rather than, as in the case of the other antibodies, as the

\footnotetext{
3 Cohn Fraction II, supplied by Hyland Laboratories, Los Angeles, Calif.
} 
TABLE II

Relative behavior of antistreptococcal diphosphopyridine nucleotidase (ASDA) and known specific antibodies in streptococcal disease

\begin{tabular}{|c|c|c|c|c|c|}
\hline \multirow[b]{2}{*}{ Group } & \multirow[b]{2}{*}{ No. of patients } & \multicolumn{4}{|c|}{ Geometric mean titer } \\
\hline & & ASDA & ASO & AH & ASK \\
\hline $\begin{array}{l}\text { Acute pharyngitis } \\
\text { Conval. pharyngitis } \\
\text { Acute rheum. fever } \\
\text { Inactive rheum. fever } \dagger\end{array}$ & $\begin{array}{l}87 \\
87 \\
31 \\
18\end{array}$ & $\begin{array}{c}\text { units/ml. } \\
84 \\
226 \\
358 \\
33\end{array}$ & $\begin{array}{c}\text { units/ml. } \\
227 \\
468 \\
497 \\
41\end{array}$ & $\begin{array}{l}\text { units/ml. } \\
101^{*} \\
180^{*} \\
578 \\
60\end{array}$ & $\begin{array}{c}\text { units/ml. } \\
36^{*} \\
160^{*} \\
173 \\
30\end{array}$ \\
\hline
\end{tabular}

* The AH and ASK titers of only 25 of 87 patients with pharyngitis were studied.

$\dagger$ Adolescents or adults with inactive rheumatic fever for five or more years and known to be free of streptococcal infection for at least one year before this assay.

serum dilution closest to an arbitrary end point of the test. An increase in the ASDA titer of more than three times the standard deviation, or greater than 22 per cent was, therefore, considered significant when serum samples obtained from serial bleedings were tested simultaneously.

\section{Behavior of ASDA following acute streptococcal pharyngitis}

Eighty-seven school children who had symptoms and signs of uncomplicated acute pharyngitis, associated with throat cultures positive for Group A streptococci, were studied. Seventeen were treated with one injection of 600,000 units of benzathine penicillin intramuscularly and the remainder received symptomatic therapy only. ${ }^{4}$ Serum was collected at the initial visit during the acute stage of pharyngitis and at 21, 35 and 60 days thereafter. ASDA and ASO determinations

4 These patients were part of a controlled study of the treatment of streptococcal pharyngitis in school children now in progress at Children's Memorial Hospital in Chicago (11). were made on paired samples of acute and convalescent phase sera in each patient.

The streptococcal antibody response was analyzed in three ways: $a$ ) the geometric mean of the titers of all patients' acute phase sera was compared with that of all patients' convalescent phase sera; $b$ ) the per cent of patients whose paired sera showed a significant increase in antibody titer during convalescence was determined; and $c$ ) the per cent of patients whose acute phase sera showed high titers (see below), without subsequent increase during convalescence, was determined.

The geometric mean of ASDA titers in acute and convalescent phase sera was 84 and 226 units per $\mathrm{ml}$., respectively. The geometric mean of ASO titers in acute and convalescent phase sera was 227 and 468 units per ml., respectively. The sera of 25 of the 87 patients with pharyngitis were titrated for $\mathrm{AH}$ and ASK. There was similarly an increase in the mean titer of these antibodies during convalescence (Table II).

Significant increase in the titer of ASDA during

TABLE III

Comparison of antibody titers in paired acute and convalescent sera of 87 patients with streptococcal pharyngitis*

\begin{tabular}{|c|c|c|c|c|c|}
\hline \multirow[b]{3}{*}{$\begin{array}{l}\text { Streptococcal } \\
\text { antibody }\end{array}$} & \multirow{2}{*}{\multicolumn{2}{|c|}{ Magnitude of rise in titer }} & \multicolumn{3}{|c|}{ Per cent of patients with: } \\
\hline & & & \multirow[b]{2}{*}{$\begin{array}{c}\text { Rise in } \\
\text { titer }\end{array}$} & \multicolumn{2}{|c|}{ No rise in titer } \\
\hline & Mean & Range & & $\begin{array}{c}\text { Acute phase } \\
\text { increased } \dagger\end{array}$ & $\begin{array}{l}\text { Acute phase } \\
\text { not increased }\end{array}$ \\
\hline $\begin{array}{l}\text { ASDA } \\
\text { ASO } \\
\text { ASDA or ASO }\end{array}$ & $\begin{array}{c}\text { units/ml. } \\
197 \\
454\end{array}$ & $\begin{array}{c}\text { units/ml. } \\
20-1,970 \\
66-2,400\end{array}$ & $\begin{array}{l}63 \\
62 \\
75\end{array}$ & $\begin{array}{r}9 \\
8 \\
17\end{array}$ & $\begin{array}{r}28 \\
30 \\
8\end{array}$ \\
\hline
\end{tabular}

* Seventeen patients were treated with penicillin. The remainder had mild, uncomplicated infections and received symptomatic treatment only (see text).

+ The acute phase sera of these patients had increased titers and the titer of their convalescent sera did not fall. Titers were considered "increased" if ASDA was greater than 200 units per ml. or ASO was greater than 500 units per ml. 


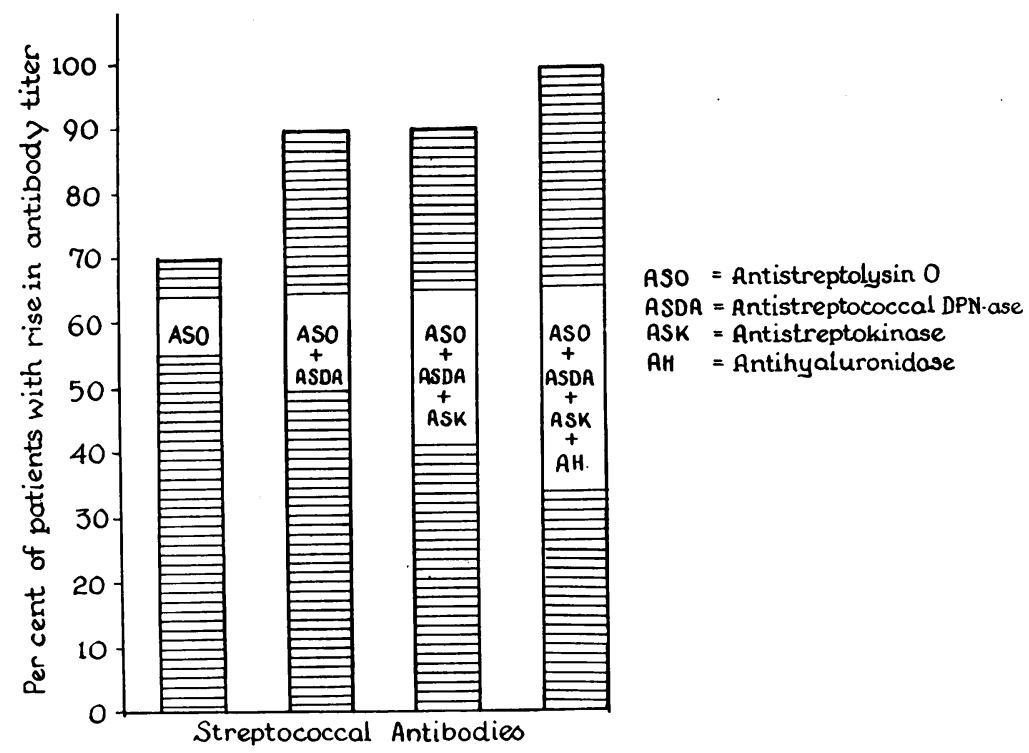

Fig. 1. Rise in Antibodies Following Uncomplicated Group A Streptococcal Pharyngitis in School Children

convalescence was observed in the sera of 63 per cent of these children. The ASO titer increased in 62 per cent of the same patients. A rise in the titer of either ASDA or ASO occurred in 75 per cent of patients (Table III).

Nine per cent of patients exhibited acute phase ASDA titers greater than 200 units per ml. which did not increase or decrease during convalescence. On the basis of distribution curves made for streptococcal antibody titers in this group of patients, levels of 200 units of ASDA were considered to be approximately comparable to 500 units of ASO. Eight per cent of patients had initial ASO titers that were greater than $\mathbf{5 0 0}$ units per ml. and did not change during convalescence.

It is often difficult to detect antibody responses to infection in patients when serum levels are already considerably increased during the acute phase of the disease. It was therefore necessary to treat the data of such patients as a separate group from those considered to have "no antibody response" and to reserve the latter category for patients whose titers were not at high levels during the acute phase and did not increase during convalescence.

By these criteria 28 per cent of patients with streptococcal pharyngitis had no ASDA response and 30 per cent had no ASO response. Only 8 per cent had no response of either titer (Table III).

\section{The relative sensitivity of $A S D A$ to three other antibody tests in acute pharyngitis}

Of the 87 school children with acute streptococcal pharyngitis, 32 patients were selected for multiple antibody determinations. The patients selected had uncomplicated acute pharyngitis which subsided promptly without antibiotic therapy. All had throat cultures positive for Group A streptococci. A significant increase in ASO titer occurred in 69 per cent of the group. When determinations of ASDA were made in addition, 90 per cent of patients showed an increase in the titer of either antibody. The addition of antistreptokinase measurements in the same sera did not increase the number of significant antibody responses. When the antihyaluronidase determination was also made, however, 100 per cent of the cases showed a significant rise in the titer of at least one of the four antibodies (Figure 1). Of the above group of 32 patients, there were 25 in whom determinations were made of all four streptococcal antibodies in all acute and convalescent sera. Antibody titers increased during convalescence or were elevated initially during the 
TABLE IV

Comparison of four streptococcal antibody titers in paired acute and convalescent sera of 25 patients with streptococcal pharyngitis who did not receive penicillin therapy

\begin{tabular}{ccc}
\hline \hline \multirow{2}{*}{$\begin{array}{c}\text { Streptococcal } \\
\text { antibody }\end{array}$} & \multicolumn{2}{c}{ Per cent of patients with: } \\
\cline { 2 - 3 } & $\begin{array}{c}\text { Antibody } \\
\text { response* }\end{array}$ & $\begin{array}{c}\text { No antibody } \\
\text { responsef }\end{array}$ \\
\hline ASDA & 80 & 20 \\
ASO & 92 & 8 \\
AH & 68 & 32 \\
ASK & 40 & 60
\end{tabular}

* These patients' sera showed a significant increase in titer during convalescence or showed high titers during the acute phase of illness which did not fall during convalescence.

† These patients' acute phase sera showed low titers which failed to increase during convalescence.

acute phase of illness with the following frequency: ASO, 92 per cent; ASDA, 80 per cent; AH, 68 per cent; and ASK, 40 per cent (Table IV).

\section{Behavior of $A S D A$ in acute rheumatic fever}

The sera of 31 young men with acute rheumatic fever ${ }^{5}$ had mean ASDA and ASO titers of 358 and 497 units per ml., respectively (Table II). A more complete antibody study of this group of patients with acute rheumatic fever is shown in Table V. Titers were found to be increased above usual levels for this age group with the following frequency: ASDA, 87 per cent (130 units per ml. or greater) ; ASO, 87 per cent (250 units per ml. or greater); $\mathrm{AH}, 76$ per cent (256 units per $\mathrm{ml}$. or greater) ; and ASK, 63 per cent (160 units per ml. or greater). These so-called "upper normal limits" were approximately twice the titers encountered in pools of sera from healthy individuals in this age group.

A combination of ASO and ASDA titers showed increased levels of either antibody in 94 per cent of the rheumatic fever patients' sera. Combination of the ASO with either the ASK or the $\mathrm{AH}$ test also detected increased levels of antibodies in 94 per cent of patients. When all four antibodies were determined, all patients showed an increase of at least one of the four titers.

It is noteworthy that the mean ASDA titer in the acute rheumatic fever patients was somewhat

5 These sera were kindly supplied by the staff of Naval Medical Research Unit No. 4, Great Lakes Naval Training Center, Great Lakes, Ill. greater than that observed in the patients with uncomplicated streptococcal pharyngitis. In this respect also, the ASDA titer behaved similarly to the other streptococcal antibodies in both groups of patients (Table II).

The behavior of ASDA titers in patients with inactive rheumatic fever

A group of 18 young adults who had had rheumatic fever at least five years previously and were proven to be free of streptococcal infections for at least the past year was studied. During this time throat cultures made routinely at each visit were negative and there was no rise in ASO, ASK or $\mathrm{AH}$ antibody titers at bimonthly examinations. The ASDA titers of the same sera were uniformly low as indicated by a mean titer of 33 units per ml. (Table II).

In vitro compared with in vivo DPNase production of strains of Group $A$ streptococci

The in vitro production of DPNase by Group A streptococci isolated from patients with pharyngitis was related to the ASDA antibody response in the sera of the same patients. Sixteen strains were recovered and cultured in Todd-Hewitt broth. The culture supernates were analyzed for DPNase activity by the method of Bernheimer, Lazarides and Wilson (4). Six strains did not produce DPNase in vitro. These included Types 1, 3, 12 and 19. Ten strains of streptococci produced DPNase in broth. These included Types 6, 12 and two "untypable" strains. There was a significant ASDA response in four of the six patients from whom "non-DPNase producing organisms" were recovered and in 7 of $10 \mathrm{pa}$ -

TABLE V

Antibody titers in 31 patients with acute rheumatic fever

\begin{tabular}{lccc}
\hline \hline $\begin{array}{c}\text { Streptococcal } \\
\text { antibody }\end{array}$ & $\begin{array}{c}\text { Per cent } \\
\text { increased* }\end{array}$ & $\begin{array}{c}\text { Geometric } \\
\text { mean }\end{array}$ & Range \\
\hline & & units $/ \mathrm{ml}$. & units $/ \mathrm{ml}$. \\
ASDA & 87 & 358 & $25-2,000$ \\
ASO & 87 & 497 & $50-1,250$ \\
AH & 76 & 578 & $16-8,000$ \\
ASK & 63 & 173 & $20-1,280$ \\
\hline
\end{tabular}

* Titers considered higher than the usual range encountered in this age group in the absence of known recent infections were as follows: ASDA, 130 units per ml. or more ; ASO, 250 units per ml. or more; $\mathrm{AH}, 256$ units per ml. or more: ASK, 160 units per ml. or more. 
TABLE VI

In vitro production of diphosphopyridine nucleotidase

(DPNase) by 16 strains of Group $A$ streptococci isolated from 16 patients with pharyngitis

whose ASDA titers were determined in acute and convalescent phase sera

\begin{tabular}{lcc}
\hline \hline $\begin{array}{c}\text { In vitro DPNase } \\
\text { production }\end{array}$ & No. of strains & $\begin{array}{c}\text { No. of patients with increase } \\
\text { in ASDA }\end{array}$ \\
\hline Positive & 10 & 7 \\
Negative & 6 & 4 \\
Total & 16 & 11 \\
\hline
\end{tabular}

tients from whom "DPNase producing organisms" were cultured (Table VI).

Of particular interest were the four patients whose strains failed to produce DPNase in vitro but whose sera showed a rise in ASDA following infection. Of these strains, one was Type 3 , one was Type 12 and two were Type 1 . No significant correlation was observed, therefore, between in vitro and in vivo production of DPNase.

\section{DISCUSSION}

The data presented confirm previous observations that ASDA activity of human serum has characteristic properties of specific streptococcal antibody. In common with most antibodies ASDA is stable upon heating at $56^{\circ} \mathrm{C}$., is associated with the $\gamma$-globulin fraction of serum and is species specific in its inhibition. Its failure to neutralize DPNase derived from beef spleen is in accord with the observations on species specificity by Kellner, Freeman and Carlson (5) who showed that ASDA could not neutralize DPNase derived from Neurospora crassa. The latter authors also showed that multiple injections of streptococcal DPNase in rabbits resulted in the appearance of progressively high titers of ASDA in their sera.

The data presented in this study demonstrate closely parallel behavior of ASDA titers and of ASO, AH and ASK titers following proven streptococcal infections. The behavior of the latter three antibodies was similar to that observed in other studies (12-15). The ASDA titer seemed to be approximately as sensitive as the ASO and somewhat more sensitive than AH and ASK titers in detecting antecedent streptococcal disease.

No peculiarity or atypical behavior of ASDA was noted in patients with acute rheumatic fever.
Like the other streptococcal antibody studies, mean titers of ASDA were somewhat higher in acute rheumatic fever patients' sera than in the sera of patients with uncomplicated streptococcal infection. This tendency of the rheumatic host to show greater streptococcal antibody levels has been reported repeatedly (13). The behavior of ASDA confirms the hyperimmune response of rheumatic fever patients to streptococcal products but sheds no further light on the pathogenesis of the disease.

The determination of the relative frequency of "increased" levels of various streptococcal antibody titers is only an estimate. There is, of course, no absolute level of antibody beyond which titers may be considered abnormally high. The range of titers of a given population varies with geographical location, age and season. The critical levels above which titers were regarded as "increased" in acute phase sera in this study were arbitrarily set at titers that are not usually exceeded in comparable populations free of recent streptococcal disease $(12,16)$. These levels were twice the titers of pooled sera obtained from such populations. It is acknowledged that the order of frequency of "increased" levels of the various antibodies will vary somewhat if different critical limits are assigned to one or the other. The purpose of this study, however, was more to determine the relative pattern of behavior of ASDA to other antibodies than to determine the "superiority" of one to the other as a test for antecedent streptococcal disease. The similarity of the behavior of ASDA to the other antibodies is more to be stressed than minor differences.

When antibody titers are already at high levels prior to streptococcal infection, it is frequently difficult to detect a further increase following reinfection. This is especially true because the methods employed for measuring antibodies can detect reliably only relatively large increments in titer $(0.2 \log$ titer $)$. This difficulty is often encountered when ASO is measured in a population heavily cross infected with Group A streptococci (16). Thus, a patient whose initial ASO titer is 1,000 units per ml. may sustain a new streptococcal infection which increases his titer to 1,250 units per $\mathrm{ml}$. This represents an increment of approximately $0.1 \mathrm{log}$ titer whereas the method commonly employed cannot detect an increment of less 
than $0.2 \mathrm{log}$ titer with reliability. The same arithmetic increment of 250 units would be readily measured if the initial ASO titer were low.

In this study, therefore, patients were classified as "no antibody response" when their acute phase titer was not at high levels and when they failed to demonstrate an increase in titer during convalescence (Tables III and IV).

Poor correlation was observed between in vitro production of DPNase and the ASDA response in vivo. A similar situation exists in the case of streptococcal hyaluronidase (17). Lazarides and Bernheimer found that extracellular production of DPNase was limited to certain strains of streptococci among a large variety of bacterial species studied. Fifty-five per cent of the streptococcal strains tested produced DPNase in vitro and these were distributed mostly among Serotypes 3, 4, 6 and 12. Types 1, 5, 14, 19 and 24 usually did not produce the enzyme in broth cultures (18).

In the present study, the type distribution of the four strains that failed to produce DPNase in vitro but stimulated ASDA responses in vivo was of interest. Two were of types usually associated with good "DPNase producers" (Types 3 and 12) and two were strains of Type 1, usually associated with poor "DPNase producers." Apparently strain variation, with regard to DPNase in vitro production, occurs within the same serotype and, in addition, DPNase formation in broth cannot be used to predict the elaboration of this enzyme in the human host.

The ASDA antibody determination appears to be an accurate and relatively practical test for the study of human streptococcal disease. In many ways the system and the technical procedure are less complicated than either the antistreptokinase or antihyaluronidase determinations and some of the reagents are better defined and more readily available. It offers no particular advantage over the ASO titration but should be a useful adjunct to it in increasing the accuracy of diagnosis of antecedent streptococcal infection.

\section{SUM MARY}

Serum antistreptococcal diphosphopyridine nucleotidase activity (ASDA) was studied in patients with rheumatic fever and in those with uncomplicated streptococcal pharyngitis, and was compared with the behavior of antibodies to other known streptococcal extracellular enzymes.

Serum ASDA showed characteristic properties of a serum antibody: it was relatively heat stable, associated with $\gamma$-globulins, and species specific in its inhibition.

ASDA behaved in closely parallel fashion to other streptococcal antibodies tested in human sera. Increased ASDA was found approximately as frequently as increased antistreptolysin $\mathrm{O}$ and somewhat more frequently than increased antihyaluronidase or antistreptokinase titers.

Like the other streptococcal antibodies studied, mean ASDA titers were somewhat higher in acute rheumatic fever patients' sera than in the sera of patients with uncomplicated streptococcal infection. After prolonged freedom from streptococcal infection, ASDA titers were uniformly low in rheumatic subjects. There was, therefore, no evidence of atypical behavior of ASDA in rheumatic fever compared with other streptococcal antibodies.

Increases in ASDA titers in the sera of patients convalescent from streptococcal pharyngitis were not always associated with in vitro production of diphosphopyridine nucleotidase by the infecting strain, and vice versa.

\section{ACKNOWLEDGMENT}

Mr. Delano Pfeifle participated in these studies during the tenure of a Medical Student Fellowship from the National Foundation.

\section{REFERENCES}

1. Carlson, A. S., Kellner, A., Bernheimer, A. W., and Freeman, E. B. A streptococcal enzyme that acts specifically upon diphosphopyridine nucleotide: Characterization of the enzyme and its separation from streptolysin O. J. exp. Med. 1957, 106, 15.

2. Kellner, A., Bernheimer, A. W., Carlson, A. S., and Freeman, E. B. Loss of myocardial contractility induced in isolated mammalian hearts by streptolysin O. J. exp. Med. 1956, 104, 361.

3. Carlson, A. S., Kellner, A., and Bernheimer, A. W. Selective inhibition by preparations of streptococcal filtrates of the oxidative metabolism of mitochondria procured from rabbit myocardium. J. exp. Med. 1956, 104, 577.

4. Bernheimer, A. W., Lazarides, P. D., and Wilson, A. T. Diphosphopyridine nucleotidase as an extracellular product of streptococcal growth and its possible relationship to leukotoxicity. J. exp. Med. 1957, 106, 27. 
5. Kellner, A., Freeman, E. B., and Carlson, A. S. Neutralizing antibodies to streptococcal diphosphopyridine nucleotidase in the serum of experimental animals and human beings. J. exp. Med. 1958, 108, 299.

6. Kaplan, N. O., Colowick, S. P., and Mason, A. Neurospora diphosphopyridine nucleotidase. J. biol. Chem. 1958, 191, 473.

7. Rantz, L. A., and Randall, E. Modification of technic for determination of antistreptolysin titer. Proc. Soc. exp. Biol. (N. Y.) 1945, 59, 22.

8. Christensen, L. R. Methods for measuring the activity of components of the streptococcal fibrinolytic system and streptococcal desoxyribonuclease. J. clin. Invest. 1949, 28, 163.

9. Harris, S., and Harris, T. N. The measurement of neutralizing antibodies to streptococcal hyaluronidase by a turbidometric method. J. Immunol. 1949, 63, 233.

10. Swift, H. F., Wilson, A. T., and Lancefield, R. C. Typing group A streptococci by $\mathrm{M}$ precipitation reaction in capillary pipettes. J. exp. Med. 1943, 78, 127.

11. Siegel, A. C., Stollerman, G. H., and Johnson, E. E. Studies on the incidence, diagnosis, treatment and non-suppurative complications of group A streptococcal infections in a general pediatric population with particular reference to the attack rate and prevention of rheumatic fever. In preparation.
12. Stollerman, G. H., Lewis, A. J., Schultz, I., and Taranta, A. Relationship of immune response to group A streptococci to the course of acute, chronic and recurrent rheumatic fever. Amer. J. Med. 1956, 20, 163.

13. McCarty, M. The immune response in rheumatic fever in Rheumatic Fever, Lewis Thomas, Ed. Minneapolis, University of Minnesota Press, 1952.

14. McCarty, M. The antibody response to streptococcal infections in Streptococcal Infections, Maclyn McCarty, Ed. New York, Columbia University Press, 1954.

15. Quinn, R., and Liao, S. A comparative study of antihyaluronidase, antistreptolysin $\mathrm{O}$, antistreptokinase, and streptococcal agglutination titers in patients with rheumatic fever, acute hemolytic streptococcal infections, rheumatoid arthritis and non-rheumatoid forms of arthritis. J. clin. Invest. 1950, 29, 1156.

16. Rantz, L. A., Randall, E., and Rantz, H. H. Antistreptolysin "O." A study of this antibody in health and in hemolytic streptococcus respiratory disease in man. Amer. J. Med. 1948, 5, 3.

17. Crowley, N. Hyaluronidase production by hemolytic streptococci of human origin. J. Path Bact. 1944, $56,27$.

18. Lazarides, P. D., and Bernheimer, A. W. Association of production of diphosphopyridine nucleotidase with serological type of group A streptococcus. J. Bact. 1957, 74, 412. 